\title{
Comparative Analysis of Epidemiological Indicators of the Prevalence and Incidence of Epilepsy among Young Men on the Example of Kharkiv and Transcarpathian Regions in Ukraine
}

\author{
Voitiuk $A^{*}$ and Litovchenko T \\ Department of Neurology and Child Neurology, Ukraine
}

*Corresponding author: Anna Voitiuk, Department of Neurology and Child

Neurology, Kharkiv Medical Academy of Postgraduate Education, Ukraine.

Received Date: April 19, 2019

Published Date: April 26, 2019

\begin{abstract}
Recently, quite a lot of publications on the problems of epilepsy in women have appeared. However, we should not forget that this disease affects men. Therefore, the aim of this work is to conduct a population-statistical study of epilepsy among young men 18-44 years old in the Kharkiv region by recording and comparing the results with the young men of the Transcarpathian region. Also, the main task was to compile registers of patients with epilepsy, which is one of the urgent tasks to optimize medical care.
\end{abstract}

\section{Introduction}

Epilepsy is one of the most common neuropsychiatric diseases. According to the consensus of the International League against epilepsy (International League Against Epilepsy, ILAE) and International Bureau for epilepsy (International Bureau for Epilepsy, IBE), epilepsy is a disease of the brain defined by any of the following conditions:

- $\quad$ At least two unprovoked (or reflex) seizures occurring $>24$ h apart

- $\quad$ One unprovoked (or reflex) seizure and a probability of further seizures similar to the general recurrence risk (at least $60 \%$ ) after two unprovoked seizures, occurring over the next 10 years

- $\quad$ Diagnosis of an epilepsy syndrome [1].

Epilepsy is an actual medical and social problem. The prevalence of this disease in developed countries is 5-10 cases per 1 thousand population. According to the results of population studies conducted in developed countries, the incidence of epilepsy ranges from 0.28 to 0.53 per 1 thousand population. In the CIS countries, the prevalence varies from 0.96 to 10 cases per 1,000 population [2].
There are differences between the prevalence and incidence of epilepsy in Europe and Ukraine, as well as the heterogeneity of the prevalence of epilepsy in different regions of Ukraine. In Ukraine suffer from epilepsy on average 50-73 per 100,000 population. In addition, the average incidence in men $(50.7$ per 100,000$)$ is slightly higher than in women (46.2 per 100,000) [3].

\section{Aim}

The purpose of this study is to conduct a population-statistical study of epilepsy among young men 18-44 years old in the Kharkiv region by recording and comparing the results with young men in the Transcarpathian region.

\section{Materials and Methods}

For the study, information from medical records was used: outpatient records, patient's medical history. In addition, the study used statistical analysis and methods of descriptive and analytical epidemiology of disease prevalence in the period from 2015 to 2017. The main material was collected by filling in a specially designed registration card of epilepsy, as the approved reporting forms show the overall prevalence and incidence in young men with a certain pathology. Based on the data obtained, a register 
of patients with paroxysmal conditions was created, which is accumulated for observation.

Another advantage of the register is the registration of other paroxysmal conditions, such as febrile seizures, which are associated with risk factors for the development of epilepsy. Consequently, register data can contribute to the early detection of risk factors for epilepsy, patient monitoring and secondary prevention of epilepsy.

\section{Result}

In this article, we conduct a comparative analysis of epidemiological indicators, namely, prevalence and incidence. To do this, consider the population of Kharkiv and Transcarpathian regions separately [4,5]. Kharkiv region, in contrast to the Transcarpathian, is one of the most urbanized in Ukraine. The population of these regions is presented in the tables below (Table $1 \& 2)$.

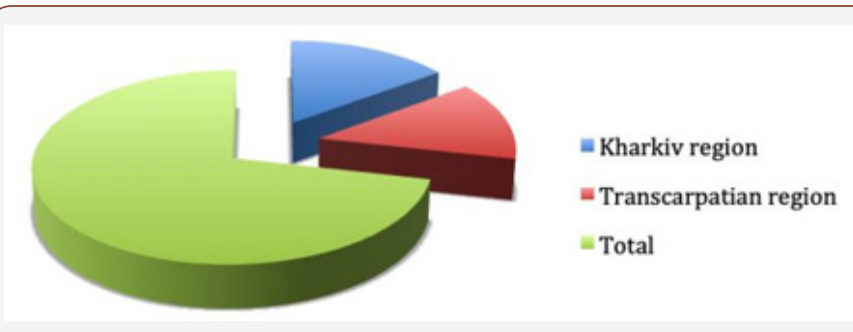

Figure 1: The number of young men with epilepsy.

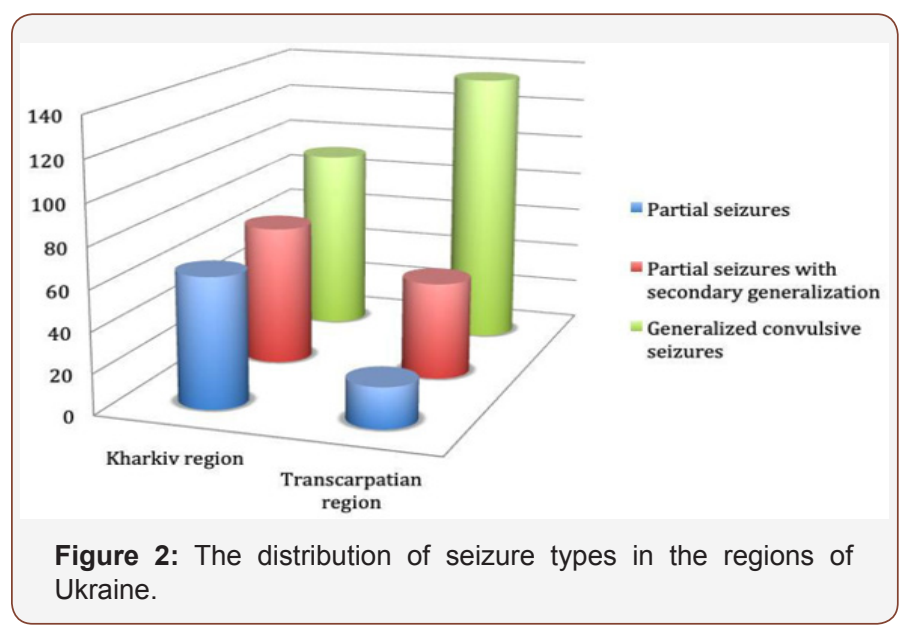

Prevalence is the total number of reported cases of disease, both previously identified and first encountered in a given population. In Ukraine, the prevalence of epilepsy is 68.7 per 100,000 population. The highest prevalence for epilepsy was registered in the Volyn region (222.7 per 100,000 population), Transcarpathian (185.3 per 100,000 population), Cherkasy ( 91.5 per 100,000 population) regions, the lowest - in the Khmelnytsky (41.0 per 100000 population), Ternopil (35.1 per 100000 population), Luhansk (27.7 per 100000 population) regions. Incidence is the number of diseases first recorded in a calendar year among the population of a given population. The incidence of epilepsy in Ukraine is 5.7 per 100,000 population. The highest incidence of epilepsy is observed in Volyn (16.5 per 100000 population) Zakarpattia (10.8 per 100 000 population), Lviv (11.5 per 100000 population) regions, and the lowest - in Ternopil (2.9 per 100000 population), Chernivtsi (2.7 per 100000 population), Sumy (1.6 per 100000 population) regions [3]. In the world, the incidence of epilepsy varies from 11 to 190 per 100,000 population, accounting for 52-70 in the UK, 80100 in Italy, 72 in Norway, 50 per 100,000 in Germany [2].

Thus, on the basis of the above data, it is clear that the incidence of epilepsy in the Transcarpathian region is higher than in the Kharkiv region. However, in general, it is lower than in developed European countries.

Discussion: In the analysis of the 1075 men with epilepsy at the age of 18-75 years it was established that in the Kharkiv region the number of patients 18-44 years totaled 224 persons. However, in the Transcarpathian region this indicator was 204 persons (Figure 1).

Table 1: Population in the Kharkiv region.

\begin{tabular}{|c|c|c|c|c|}
\hline \multirow[b]{2}{*}{ Year } & \multirow[b]{2}{*}{ Total } & \multicolumn{2}{|c|}{ Including } & \multirow[b]{2}{*}{ Ukraine } \\
\hline & & $\begin{array}{c}\text { Urban } \\
\text { Population }\end{array}$ & $\begin{array}{c}\text { Rural } \\
\text { Population }\end{array}$ & \\
\hline 2015 & 2715666 & 1433320 & 1282346 & 42759700 \\
\hline 2016 & 2702980 & 1430165 & 1272815 & 42590900 \\
\hline 2017 & 2685552 & 1419469 & 1266083 & 42414900 \\
\hline
\end{tabular}

In the Kharkiv region, partial seizures prevailed among young men - 135 (31.8\%), while generalized convulsive seizures prevailed in the Transcarpathian region - 136 (30.2\%) (Table 2).

Table 2: Population in the Transcarpathian region.

\begin{tabular}{|c|c|c|c|c|}
\hline \multirow{2}{*}{ Year } & \multirow{2}{*}{ Total } & \multicolumn{2}{|c|}{ Including } & \multirow{2}{*}{ Urban } \\
\cline { 3 - 4 } & & $\begin{array}{c}\text { Rural } \\
\text { Population } \\
\text { Population }\end{array}$ & \\
\hline 2015 & 1259600 & 467300 & 792300 & 42759700 \\
\hline 2016 & 1259200 & 467000 & 792200 & 42590900 \\
\hline 2017 & 1258800 & 465500 & 793300 & 42414900 \\
\hline
\end{tabular}

In young men, the idiopathic form of epilepsy prevailed in the Transcarpathian region, while in the Kharkiv region symptomatic epilepsy (Table 3) [4-6].

Table 3: The forms of epilepsy among men 18-44 years old.

\begin{tabular}{|c|c|c|c|c|}
\hline \multirow{2}{*}{ Region } & \multicolumn{3}{|c|}{ Form of Epilepsy } & \\
\cline { 2 - 5 } & Idiopathic & Cryptogenic & Symptomatic & $\begin{array}{c}\text { Form } \\
\text { Is Not } \\
\text { Installed }\end{array}$ \\
\hline $\begin{array}{c}\text { Kharkiv } \\
\text { region }\end{array}$ & 25 & 48 & 112 & 52 \\
\hline $\begin{array}{c}\text { Transcapa- } \\
\text { thian region }\end{array}$ & 131 & 101 & 5 & 1 \\
\hline
\end{tabular}

Table 4: The duration of epilepsy among men 18-44 years old.

\begin{tabular}{|c|c|c|c|c|}
\hline \multirow{2}{*}{ Region } & \multicolumn{3}{|c|}{ Duration } & \\
\cline { 2 - 5 } & $\begin{array}{c}\text { Up To 5 } \\
\text { Years }\end{array}$ & $\begin{array}{c}\mathbf{6 - 1 0} \\
\text { Years }\end{array}$ & $\begin{array}{c}\mathbf{1 1 - 1 5} \\
\text { Years }\end{array}$ & $\begin{array}{c}\text { More Than } \\
\text { 15 Years }\end{array}$ \\
\hline Kharkiv region & 14 & 26 & 32 & 164 \\
\hline $\begin{array}{c}\text { Transcarpathian } \\
\text { region }\end{array}$ & 3 & 28 & 48 & 131 \\
\hline
\end{tabular}

One of the important indicators is the duration of active epilepsy. The duration of the disease determines the course of the disease in 
the direction of complication and weighting. In both regions, the duration of the disease is more than 15 years, which indicates a lack of effective treatment (Table 4).

\section{Conclusion}

In this research we studied the clinical and epidemiological indicators in young men on the example of various regions of Ukraine, which will make it possible to improve the system of rendering specialized medical care. Thus, the compilation of patients' registers with epilepsy is one of the urgent tasks to optimize the medical care.

\section{Acknowledgement}

None.

\section{Conflict of Interest}

No conflict of interest.

\section{References}

1. Fisher RS, Acevedo C, Arzimanoglou A, Bogacz A, Cross JH, et al. (2014) A practical clinical definition of epilepsy. Epilepsia 55(4): 475-482.

2. Banerjee PN (2009) The descriptive epidemiology of epilepsy. In: PN Banerjee, D Filippi, W Clen Hauser (Eds.), Epilepsy Res 85: 31-45

3. Litovchenko, TA (2010) Epilepsy: terminology, epidemiology, classification, etiology, pathogenesis. In: TA Litovchenko (Ed.), Neuro News No 2C: 27-33.

4. Main indicators of health of the population and activity of the health care institutions of Kharkiv oblast for 2006-2017 [Electron resource] / KPIZ "Kharkiv Oblast Information-Analytical Center for Medical Statistics" of the Kharkiv Oblast State Administration of Health Administration Access Mode.

5. The Main Department of Statistics in the Transcarpathian Region [Electron Resource]. - Access mode.

6. Panayiotopoulos CP (2007) Epileptic Syndromes and their Treatment. In: CP Panayiotopoulos (Ed.), Springer-Velag, UK, p. 578. 